\title{
Using Online Discussions to Develop the Entrepreneurial Mindset in Environmental Engineering Undergraduates: A Case Study
}

https://doi.org/10.3991/ijep.v9i3.9491

\author{
Lisa B. Bosman ${ }^{(凶)}$, Nathalie Duval-Couetil \\ Purdue University, Indiana, USA \\ lbosman@purdue.edu \\ Brooke Mayer, Patrick McNamara \\ Marquette University, Wisconsin, USA
}

\begin{abstract}
Entrepreneurship is an important aspect of the U.S. and global economy. As such, developing an entrepreneurial mindset is crucial for both engineering students and practicing engineers. The purpose of this paper is to investigate the role of online discussions, as a pedagogical approach, in the development of the entrepreneurial mindset. Online discussions prompts were developed using the Kern Engineering Entrepreneurial Network (KEEN) framework as a guide. The KEEN framework proposes an entrepreneurial mindset can be fostered in students by stimulating curiosity, strengthening connections, and creating value. This paper describes the methodology and rationale that served as the foundation for this exploratory study. Examples are provided for online discussion prompts developed and administered in two different environmental engineering undergraduate courses: Introduction to Environmental Engineering (three credit, undergraduate, online course offered during two different summer sessions) and Seminar in Environmental Engineering (one credit, undergraduate level, face-to-face course offered during one semester). Quantitative and qualitative methods were used to analyze and assess potential impacts of online discussion prompt use. The findings provide lessons learned for integrating the KEEN framework into undergraduate engineering courses through online discussions.
\end{abstract}

Keywords—Entrepreneurial mindset, online discussions, writing

\section{$1 \quad$ Introduction}

\subsection{Motivation for the case study}

The entrepreneurial mindset has been characterized as a "growth-oriented perspective through which individuals promote flexibility, creativity, continuous innovation, and renewal" [1]. Not only is the entrepreneurial mindset beneficial for establishing new companies, it is also essential to the vitality and growth of existing firms and or- 
ganizations to foster competitiveness and survival. In recent years, promoting an entrepreneurial mindset in students has received acceptance and praise within the engineering education community [2-4]. In this domain, it is increasingly acknowledged that engineers need to improve upon, design and innovate new products and services with emphasis on the value to users, as opposed to the traditional engineering concepts associated with technical and functional performance features $[5,6]$. This is true whether they choose to work in startups or existing organizations. Engineering students themselves also recognize the potential value of entrepreneurship knowledge to their career prospects and choices [7, 8]. Given these realities, engineering faculty and administrators are placing a greater focus on disseminating resources to assist engineering faculty in fostering the entrepreneurial mindset into existing engineering courses $[9,10]$.

\subsection{Importance of stakeholder feedback}

In spring 2015, the authors conducted exploratory research to understand the potential needs and benefits associated with fostering an entrepreneurial mindset among engineering students. The authors developed a survey and collected data from industry representatives $(n=19)$, engineering faculty $(n=21)$, and engineering students $(n=$ 363). The survey asked participants to reflect on the different categories of entrepreneurially-minded skills being sought by employers. In addition, the survey asked participants to consider what categories of entrepreneurially-minded skill development should be offered in engineering classrooms. A student focus group was also conducted with seven undergraduate engineering students with the overall goal to assess interest and awareness related to entrepreneurship skills and the entrepreneurial mindset, while also identifying challenges to engaging students in associated extra-curricular activities and events. Results from the survey and focus group highlighted the need to incorporate mindset activities at every level of the engineering curriculum, not just senior design courses [11, 12].

There are many different formats, pedagogical approaches, and opportunity for engineering students to seek out entrepreneurial skillsets, such as:

- Capstone design courses

- Design-based "traditional" engineering courses

- Entrepreneurially-focused extra-curricular activities

- Enrolling in minors or badge programs with an entrepreneurship and/or innovation emphasis

However, from a faculty perspective, some engineering educators find it difficult to add yet another topic into rigorous and content-filled engineering courses. In response, a group of faculty decided to conduct an exploratory approach to determine a pedagogical approach to optimize teaching effectiveness and efficiency related to incorporating the entrepreneurial mindset into traditional engineering courses. Online discussions were chosen as the faculty group believed this pedagogical approach provided an ideal start for incorporating the entrepreneurial mindset into undergraduate engineering curriculum; regardless of whether the course is online or face-to-face, online discussions 
offer ease in implementation without taking away from the rigor associated with engineering content.

\subsection{Research objectives}

This case study offers engineering educators insight into one approach for incorporating the entrepreneurial mindset into the engineering classroom with limited disruption to in-class lecture and activities. The objectives of this paper are twofold. First, the paper will provide examples of discussion prompts deployed in two different environmental engineering classrooms, including lessons learned and engineering educator tips for deploying online discussions. Second, the paper will describe evaluation techniques used in an attempt to assess student learning, including student self-reported perceptions related to student learning inside and outside the classroom, and student self-reported perceptions related to components of the entrepreneurial mindset. The study will be guided by the following research questions:

- What is the role of online discussions, as a pedagogical approach, in the development of the entrepreneurial mindset?

- How can student learning be assessed to evaluate the effectiveness of online discussions developed within the context of the entrepreneurial mindset?

The overall intent is to show how discussion prompts can be used as a tool to promote practice and development of the entrepreneurial mindset. The next section, Background, will provide an overview of innovation and entrepreneurship frameworks. The Methods section will describe the two environmental engineering courses impacted, the discussion prompts developed and deployed, and an explanation of the analysis methods. The Analysis and Results section will provide a summary of the results, including both quantitative and qualitative findings. The Discussion and Implications section will provide major project takeaways with particular emphasis on the relevance and importance for engineering education, and recommendations for future classroom implementations. The final section, Conclusions and Future Work, will provide a holistic perspective of the manuscript, stating limitations, highlighting the motivation, and suggesting recommendations or future research.

\section{Background}

\subsection{Overview of Innovation and Entrepreneurship Frameworks [13]}

We drew on several existing innovation and entrepreneurship frameworks that address the behaviors, characteristics, skills, or attributes associated with the entrepreneurial mindset. Considering the insights offered through von Brocke et al. [14], it is important to note that the authors focused on frameworks commonly used by entrepreneurship engineering educators in the United States. 


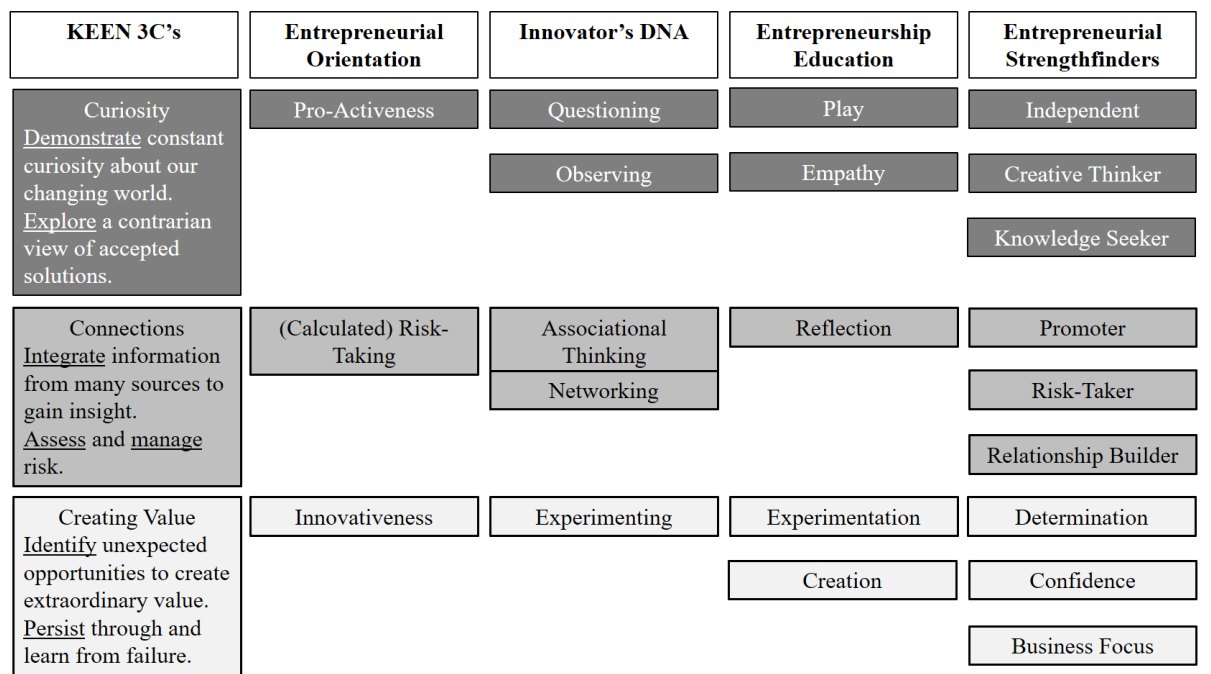

Fig. 1. Summary of Entrepreneurially-Minded Frameworks

The KEEN (Kern Entrepreneurial Engineering Network) framework [15] takes an anecdotal approach and proposes what are referred to as the $3 \mathrm{C}$ 's of the entrepreneurial mindset:

- Curiosity (demonstrating constant curiosity about our changing world and exploring a contrarian view of accepted solutions)

- Connections (integrating information from many sources to gain insight, as well as assessing and managing risk)

- Creating Value (identifying unexpected opportunities to create extraordinary value and persisting through and learning from failure). The Entrepreneurial Orientation framework $[16,17]$ was the result of empirical research identifying pro-activeness, [calculated] risk-taking, and innovativeness as three critical characteristics for entrepreneurial mindsets. The Innovator's DNA, which resulted from a six-year study of entrepreneurs and executives [18], suggested that innovative entrepreneurs exhibit skills including associating, questioning, observing, experimenting, and networking. The book, "Teaching Entrepreneurship: A Practice Based Approach" [19], drew from years of experience training entrepreneurship educators and anecdotal evidence to posit that entrepreneurial orientation stems from practicing empathy, play, reflection, experimentation, and creation. Finally, the Entrepreneurial Strengthsfinder, which emerged from Gallup research [20], found that personality traits, including independent, creative thinker, promoter, knowledge-seeker, determination, confidence, risk-taker, relationship-builder, business focus, and delegator, were drivers of successful entrepreneurs.

These frameworks are summarized in Figure 1, which is toned in color to show the similarities across the frameworks. For example, KEEN's notion of Curiosity is conceptually similar to Pro-Activeness (from Entrepreneurial Orientation), Questioning 
and Observing (from the Innovator's DNA), and Play and Empathy (from Entrepreneurship Education). Although there is similarity across the frameworks, for the purpose of this study, the KEEN framework was used due to its specific focus on undergraduate engineering education.

\subsection{Introduction to the KEEN framework}

The Kern Entrepreneurial Engineering Network (KEEN), an education-focused program, was developed with support from the Kern Family Foundation. KEEN is a group of about forty U.S. universities and includes hundreds of engineering faculty, with a mission as follows: "We are a national partnership of universities with the shared mission to graduate engineers with an entrepreneurial mindset so they can create personal, economic, and societal value through a lifetime of meaningful work." The KEEN framework is a guide which can be used to curate entrepreneurial minded learning curriculum for undergraduate engineering students. The intent of the framework is to develop student behaviors and attributes which focus more on preparing students to think and design strategically, rather than simply participating in society and the workforce as an "obedient engineer".

Several educational research investigations have explored the role of the KEEN framework. Huerta and colleagues [21] used introductory engineering design artifacts and written student reflections to conduct a thematic analysis; the findings revealed student awareness, intention and action towards facets related to the entrepreneurial mindset. A different study focused on humanities courses (at a primarily engineering university), integrating the KEEN student outcomes through the development of case studies and inquiry related to real-world engineering applications, to assist students in answer the age old question - when will I ever use this? Liu and authors [22] incorporated the KEEN framework into upper-level mechanical engineering courses including Mechatronics, Heat Transfer, and Fluid Mechanics; the results provide evidence and demonstration of behaviors associated with the entrepreneurial mindset when students participate in the three-course scaffold entrepreneurially-minded problem-based learning experience. Although, these efforts have proven fruitful, limited research has focused on integrating the entrepreneurial mindset through online discussions.

\section{Methods}

\subsection{Participants, courses, and discussion prompt development}

The project deployment was conducted at a medium-sized, private, inner city university in the Midwest region of the United States. Online discussion prompts, which focused on developing curiosity, connections and creating value, were developed and deployed in two different environmental engineering courses. The discussion prompts were developed to incorporate the KEEN framework. In particular, specific attention was given to promote building interest in technical topic areas, developing an entrepreneurial mindset in students, and improving learning general course learning outcomes. 
This remainder of this section describes the details associated with the development and deployment of the discussion prompts. In both courses, participation in the discussion prompts was compulsory in that it counted towards the course grade.

Table 1 provides example discussion prompts developed for Introduction to Environmental Engineering. The course, offered as a 3-credit class, provides a vital yet fundamental foundation for understanding and evaluating the environment and related design systems with consideration for environmental quality control. The courses was delivered during two different 8-week summer sessions (2015 \& 2016) using the online learning management system, D2L. This course is mandatory for all engineering undergraduates enrolled in the civil engineering bachelor's degree. The faculty member developed the prompts, in collaboration with an instructional designer, by incorporating the KEEN 3C's into common topics in environmental engineering, finding opportunities to focus on stimulating curiosity, strengthening connections, and creating value. The same faculty member instructed both undergraduate sessions; in total, twelve students enrolled in the class and participated in the discussions. The course enrollment numbers are typical for this course at this institution.

Table 1. Example Discussion Prompts: Introduction to Environmental Engineering [13]

1. Water Resources \& Pollutants: Are we actually running out of water or not? Take a stand and support it with explanations regarding quantity, quality, and potential stressors. Pick one of the following proposals about alternative sources of fresh water and argue in support of or against the proposal. Be sure to do some research (online or otherwise) to gather related information and viewpoints. Describe the information and potential implications of your position. Additionally, address the concerns of those who take alternate positions and suggest potentially acceptable alternatives.

- Investors propose to tow icebergs to the Middle East for use as drinking water supplies

- The City of Waukesha proposes to pipe water from Lake Michigan to augment groundwater sources in the drinking water system

- The county legislature in Texas proposes to use reclaimed water (treated wastewater) to irrigate cotton and corn fields

- Citizens in Colorado propose to use rain barrels for outdoor watering purposes (e.g., lawns, flowers, car washing)

2. Water Treatment: Make the case that tap water or bottled water is a better choice based on safety, taste, economics and convenience of each. To inform your discussion, take a look online for information about tap water treatment and cost and look at the labels of a couple different brands of bottled water to find out where the water comes from and how it is treated.

3. Wastewater Treatment: (1) Antibiotics, endocrine disrupting compounds (EDCs), pharmaceuticals and personal care products (PPCPs), and nanoparticles are considered emerging problems in wastewater treatment. Take a position about whether or not any or all of these are a problem. Describe what is currently being done about them, if anything. (2) Based on your understanding of these issues, do you think measures should be taken to keep them out of water environments in the first place? If so, what would you recommend? Do you think there should be greater focus on removing them from wastewater? If so, what kinds of things do you think should be done? Is this much ado about nothing?

Table 2 showcases examples discussion prompts developed for the Seminar in Environmental Engineering, a one-credit course delivered in a face-to-face classroom, supplemented with online discussions using the D2L learning management system. The course was deployed during the fall 2016 semester. This course featured guest speakers addressing topics such as water and wastewater treatment, storm water management and urban hydrology, air pollution, and hazardous waste management. It was a pass-orfail class using a "satisfactory" or "unsatisfactory" grading basis. Again, the faculty 
member developed the prompts by incorporating the KEEN 3C's into common topics in environmental engineering, finding opportunities to focus on promoting curiosity, encouraging connections, and creating value. Each discussion session took place for one week, requiring students to upload an initial post and a response post (responding to a peer's initial post). Students were given a grading rubric identifying expectations associated with uploading both the initial post and response post. In total, five students enrolled in the class and participated in the discussions. The course enrollment numbers are typical for this course at this institution.

Table 2. Example Discussion Prompts: Seminar in Environmental Engineering

1. Triclosan: The speaker presented his research on removing triclosan from wastewater using biochar as an innovative adsorbent. He mentioned that the FDA (Food and Drug Administration) recently banned the use of triclosan in soap products (effective in 2017). Do you think that micropollutants should be banned in all products? Why or why not? Please consider the advantages and disadvantages of these chemicals in products, people, and the environment in your responses.

2. Biosolids: The solids generated during wastewater treatment contain the solid material removed during the processes. They also have a lot of organic content, which makes them perfect for anaerobic digestion, where methane can be produced while the solids are stabilized for ultimate disposal. The final solids also can contain valuable resources such as nutrients or harmful things such as metals or pathogens. In the US, biosolids are regulated for land application under EPA Rule 503, which focuses on metal and pathogen content (https://www.epa.gov/biosolids/frequent-questions-about-biosolids). In some countries, e.g., many parts of Europe, biosolids can't be land applied, and are instead incinerated or landfilled. How do you feel about the use of biosolids for land application? Furthermore, how do you feel about biosolids-derived products such as the struvite that the speakers talked about removing? Does it have value as a fertilizer and do regulations need to shift to address this? Do you generally feel that regulations reflect the current times or do they lag behind or lead into the future?

3. Holistic Approach: "Be comfortable with being uncomfortable." This is a sentiment that the Dean promotes in her vision for engineering. The speaker echoed this in his advice at the end of the talk. Reflect on this sentiment. Do you agree or disagree? What does it mean to you? It the case of the Kinnickinnic River Watershed restoration project, one aspect of this "working outside your comfort zone" approach was to work with people/agencies/groups who you don't typically work with to take a more holistic approach to engineering projects. How can you enhance your ability to do this in your professional career? What changes in engineering curriculum would facilitate this approach?

\subsection{Description of assessment methods [13]}

The open-ended questions and the first two scale questions explored student perceptions related to learning outcomes. The latter four scale questions explore student perceptions related to the entrepreneurial mindset, as defined not only by the KEEN framework but also by other typically recognized frameworks. For example, "Formulating questions and generating own inquiries" is similar to the Innovator's DNA [18] Questioning and Associating, the Knowledge-seeker attribute of the Entrepreneurial Strengthsfinder [20], the Reflection aspect of the "Teaching Entrepreneurship: A Practice Based Approach" [19], and promoting Curiosity within the KEEN framework. As 
another example, "Exploring alternatives" is similar to Experimenting in the Innovator's DNA [18] and "Teaching Entrepreneurship: A Practice Based Approach" [19], as well as promoting Curiosity in the KEEN framework. Yet, another example, "Encouraging and understanding diverse perspectives" is comparable to Empathy in "Teaching Entrepreneurship: A Practice Based Approach" [19] and encouraging Connections in the KEEN framework.

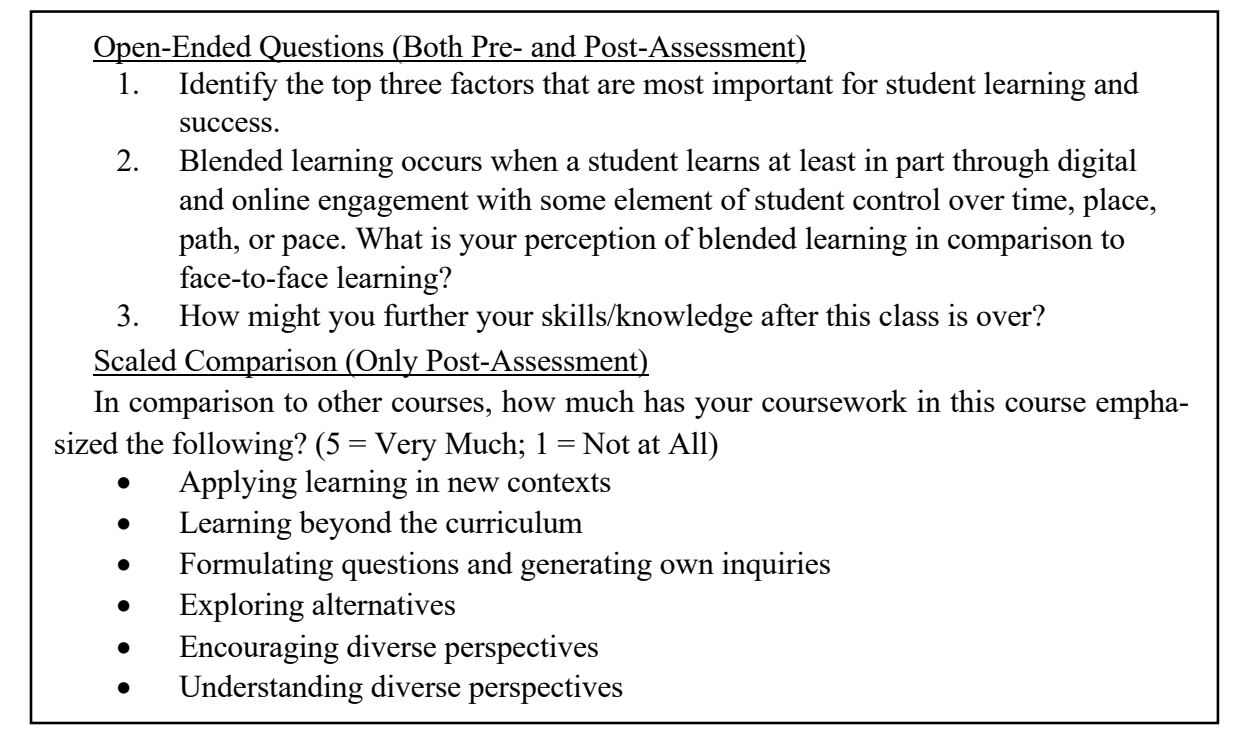

Fig. 2. IRB Approved Pre- and Post-Survey [13]

\subsection{Introduction to case study analysis}

A pre- and post- survey was developed by the researchers, approved by the Institutional Review Board, and administered to participants to investigate the research question. A summary of the pre- and post-survey is provided in Figure 2. Through an exploratory case study research design approach, the researchers examined all data sources in an attempt to understand the phenomenon under investigation; a benefit of case study approach is that investigators and researchers are able to obtain a holistic understanding of the phenomenon being considered as a result of multiple data sources [6, 23-25]. For this study, the surveys assisted researchers with developing a greater awareness of participant's behaviors, skills, and intentions towards the entrepreneurial mindset. 


\section{$4 \quad$ Analysis and Results}

\subsection{Qualitative analysis of open-ended questions (Pre- and Post-Surveys)}

Results for the qualitative open-ended questions are presented here. Question 1 asked participants to identify factors important for student success and learning. Several responses were common for both the pre- and post-survey. Example responses include course schedule, student study habits, and teacher effectiveness. In general, participant responses offered limited change from pre- to post-survey.

Question 2 asked participants to share their perceptions of blended learning (online components AND face-to-face interactions) in contrast to face-to-face learning. In comparing pre- to post-survey results, the participant responses were substantially different. In the pre-survey, only $15 \%$ of the students stated that they preferred blending learning over face-to-face learning. However, in the post-survey, $50 \%$ of the students preferred blended learning over face-to-face learning. This large percentage increase implies that students perceive blended learning (integrating online discussions into the face-to-face classroom) as a worthwhile pedagogical approach for students to meet learning objectives.

Table 3. Example Pre- and Post-Survey Responses [13]

\begin{tabular}{|c|c|}
\hline Example Pre-Survey Responses & Example Post-Survey Responses \\
\hline $\begin{array}{l}\text { - "I might review the lecture notes and read related } \\
\text { books." } \\
\text {-"Ensuring that I read through the chapter and possi- } \\
\text { bly do extra problems to get more practice." } \\
\text {-"Office hours with the teacher. Outside the realm of } \\
\text { the teacher, I would go to a library to understand } \\
\text { concepts." }\end{array}$ & $\begin{array}{l}\text { - "Continue to keep up with current events involving } \\
\text { Environmental Chemistry and its systems." } \\
\text { - "Read more news articles on science as opposed to } \\
\text { sports." } \\
\text {-"Continue to keep up with the latest research and } \\
\text { development in wastewater and drinking water treat- } \\
\text { ment." }\end{array}$ \\
\hline
\end{tabular}

Question 3 ask participants to consider how they might further their knowledge and skill development outside the classroom upon completion of the course. In comparing pre- to post-survey results, the participant responses were substantially different, as shown in Table 3. In the pre-survey, participant responses focused on resources which were either provided by the faculty instructor or offered within the university. Yet, in the post-survey, participant responses focused on the individual's capacity to keep up with real-world events, news, trends, and research to further develop their skills and knowledge. This change in perspective implies that online discussions offer students life-long learning skills re-enforcing their ability to further improve their skills outside the classroom, with limited support from instructors and the university.

\subsection{Quantitative analysis of scaled survey [13]}

Table 4 provides the quantitative post-survey results. The participants responded to the following statement: "In comparison to other courses, how much has your coursework in this course emphasized the following? $(1=$ Not at All; $5=$ Very Much $)$ " [13]. 
Table 4. Results [13] - Student Perceptions of Discussion Assignment

\begin{tabular}{|l|c|c|c|c|c|c|c|c|c|c|c|}
\hline \multicolumn{1}{|c|}{ Emphasis Area } & S1 & S2 & S3 & S4 & S5 & S6 & S7 & S8 & S9 & S10 & Avg \\
\hline 1. Applying learning in new contexts & 5 & 4 & 5 & 4 & 5 & 5 & 4 & 4 & 5 & 4 & 4.5 \\
\hline 2. Learning beyond the curriculum & 5 & 4 & 5 & 4 & 4 & 5 & 4 & 5 & 5 & 5 & 4.6 \\
\hline 3. Formulating questions and generating own inquiries & 5 & 5 & 5 & 5 & 4 & 5 & 4 & 4 & 4 & 4 & 4.5 \\
\hline 4. Exploring alternatives & 5 & 4 & 5 & 4 & 3 & 5 & 5 & 4 & 4 & 5 & 4.4 \\
\hline 5. Encouraging diverse perspectives & 4 & 4 & 4 & 5 & 4 & 5 & 5 & 5 & 5 & 5 & 4.6 \\
\hline 6. Understanding diverse perspectives & 5 & 4 & 4 & 4 & 5 & 5 & 4 & 4 & 4 & 4 & 4.3 \\
\hline
\end{tabular}

The average scores are all relatively high, however, learning beyond the curriculum and encouraging diverse perspectives received the highest scores. The initial two items (applying learning in new contexts and learning beyond the curriculum) focus on the student learning outcomes. The high scores imply the online discussions were effective pedagogical approach to attain student learning outcomes, particularly with learning beyond the curriculum. The last four items (formulating questions and generating own inquiries, exploring alternatives, encouraging diverse perspectives, understanding diverse perspective) focus on aspects associated with developing the entrepreneurial mindset, especially with encouraging diverse perspectives. In general, the high scores across all statements suggest that from a student's perspective, the KEEN-focused online discussions were effective in developing personality traits, behaviors, and skills previously linked to the development of the entrepreneurial mindset.

\section{Discussion and Implications}

\subsection{Discussion and insights}

The intent of this study was to explore the benefits of integrating the KEEN framework into two different Environmental Engineering courses.

There were two major findings related to this qualitative survey. First, the percent of students who preferred blended learning increased from $15 \%$ (before the entrepreneurially-minded discussions) to $50 \%$ (after the entrepreneurially-minded discussions). This implies that blended learning, and specifically entrepreneurially-minded online discussions, provide an ideal pedagogical approach to integrate the entrepreneurial mindset into the classroom. With respect to the research question, What is the role of online discussions, as a pedagogical approach, in the development of the entrepreneurial mindset?, entrepreneurially-minded online discussions were looked on favorable by the students. Second, in comparing Q3 (how to further knowledge acquisition) pre- to postassessment, the findings suggest that students gained awareness and recognition towards online discussions as a viable option to further skills outside the classroom while simultaneously improving learning outcomes. Thus, with respect to the research question, What is the role of online discussions, as a pedagogical approach, in the development of the entrepreneurial mindset? Students perceived entrepreneurially-minded inquiry through information literacy, synthesis, and online research, as a method to further their knowledge outside the classroom. 
With respect to the quantitative survey, the results suggest that from a student's perspective, the entrepreneurially-minded online discussions were effective in developing outcomes, behaviors, characteristics and skills previously linked to the entrepreneurial mindset. When considering the research question, How can student learning be assessed to evaluate the effectiveness of online discussions developed within the context of the entrepreneurial mindset? These findings imply that student self-reports are one approach to assessing effectiveness towards a learning outcome.

In summary, this case study provided examples of discussion prompts deployed in two different environment engineering classrooms. This provides evidence that writing assignments can easily be implemented into engineering courses without losing the rigor. Furthermore, based on instructor observation, students appeared better prepared for participation in classroom lecture. In that sense, online discussions can be viewed as an effective and efficient method for increasing student engagement in classroom activities with limited upfront work required by students. The connection to real-world principles allowed to the students to understand the practical purpose of classroom topics prior to understanding the theoretical importance offered through classroom lecture. This case study also provided examples of evaluation techniques applied in an attempt to assess student learning. These assessment techniques included student self-reported perceptions related to student learning inside and outside the classroom and student self-reported perceptions related to components of the entrepreneurial mindset. Although the evidence of attainment towards the entrepreneurial mindset is somewhat inconclusive, assessment practices are important and necessary components for obtaining and maintaining academic accreditation.

\subsection{Recommendations for deploying online discussions}

A large quantity of guidelines, best practices, and resources for facilitating online discussions can be found in the literature and through Centers for Teaching and Learning located on many university websites [26-28]. However, a number of key recommendations based on instructor feedback are provided here. These suggestions center on effectively and efficiently designing, managing, and assessing online discussions, optimizing minimal time investment and maximum student feedback.

First and foremost, it is important to clarify expectations at the beginning of the semester. This is true for both instructor expectations and student expectations. As an example, it is beneficial for the instructor to identify when he or she plans to read and provide feedback within the online discussion. This means being specific about what days and times during the week the instructor plans to access the discussion (e.g., M-F, 8-9 a.m.). Thus, students will know when [and when not] to expect instructor feedback. In the case of online discussions being deployed in large classes, instructors might find it helpful to assign student discussion leaders to help encourage timely and appropriate discussions. With respect to providing clarity for student expectations, a rubric is key $[29,30]$. A rubric not only attests to the quality expected within the discussion, but also provides requirements for minimum quantity of initial posts and response posts. Furthermore, instructor anecdotal evidence suggests that setting a weekly routine is very 
beneficial for the student. For example, the instructor might require students to provide an initial post weekly by Wednesdays and provide response posts weekly by Saturday.

\section{Conclusion and Future Work}

\subsection{Summary}

This study provided examples of discussion prompts deployed in two different environmental engineering classrooms: Introduction to Environmental Engineering and Seminar in Environmental Engineering. In addition, lessons learned and educator tips are offered to assist other educators in implementing similar types of curriculum. The case study described a variety of evaluation techniques used in an attempt to assess student learning including student self-reported perceptions related to student learning inside and outside the classroom and student self-reported perceptions related to components of the entrepreneurial mindset. This case study offered engineering educators insight into one approach for infusing the entrepreneurial mindset into the undergraduate engineering classroom. One benefit of this particular approach, using online discussion prompts, is that it afforded limited disruption to in-class lecture and activities.

\subsection{Problems and challenges addressed}

The entrepreneurial mindset, although useful for creating a new company, is also essential to the growth and vitality of existing organizations to ensure competitiveness and survival. It is increasingly acknowledged that engineers need to improve upon, innovate, and design new products and services with emphasis on the value to users, as opposed to the traditional engineering concepts associated with technical and functional features $[5,6]$. University administrators and engineering faculty, alike, are placing a greater focus on disseminating resources to assist engineering faculty in fostering the entrepreneurial mindset in existing engineering courses $[9,10]$. However, some engineering educators find it difficult to add yet another topic into rigorous and contentfilled engineering courses. This case study provided the results of one approach to do this, using online discussion prompts, showing relevance in two different environmental engineering courses.

\subsection{Value associated with the study}

Data shows that discussion prompts can be an effective pedagogical tool in online courses. This paper describes their role and gives examples of how they are developed, which can be applied to any engineering course and/or discipline. Developing, facilitating, and assessing online discussions can be done efficiently and effectively with a somewhat minor instructor time investment prior to offering the course [13, 31-34], and with limited disruption to the classroom. Moreover, online discussions deliver several benefits to the instructor and students when integrated into face-to-face classrooms and/or online course environments [35-37]. First, online discussions afford students the 
essential and indispensable time to create thought provoking responses, encouraging students to consider additional news, events, trends, and research to support their discussion posts. Second, they provide students the potential to gain additional insights and perspectives through reading and responding to other students' posts. Third, online discussions offer instructors the ability to deliver immediate feedback to students and ask additional questions to provide depth into the discussion subject. Finally, while not exclusive to entrepreneurship, it appears this approach to reflection and online discussion fosters qualities in students that are echoed in entrepreneurial frameworks; qualities that are not simply limited to the KEEN framework but across multiple entrepreneurial frameworks. This exploratory analysis offers insight into the budding implications of the activities the KEEN initiative is promoting, specifically promoting the entrepreneurial mindset in undergraduate engineering students.

\subsection{Recommendations for future work}

It is important to note potential limitations of the study. First, the small class sizes, although typical of this institution, may limit the generalizability of the results. Additionally, the study was deployed through the D2L learning management system, where the ease of use for online discussions is different from other learning management systems. Lastly, the study developed online discussions for use in two environmental engineering courses. Thus, future related research should be conducted to further validate the study with respect to reliability and repeatability; this could be done by implementing entrepreneurially minded discussions with more students and classes (e.g., increase the sample size), across various engineering courses, and implemented in different learning management systems. Furthermore, future work should continue to investigate how discussion prompts and writing prompts can be used more extensively, how the prompts can be more interactive, and what rubrics can be developed to assess learning as well as engagement and motivation. This pedagogical approach can be valuable to educators faced with developing online courses and educators looking to make their class more practical without detracting from the rigor of the material.

\section{$7 \quad$ References}

[1] Ireland, R.D., M.A. Hitt, and D.G. Sirmon, a Model of Strategic Entrepreneurship: The Construct and its Dimensions. Journal of Management, 2003. 29(6): p. 963-989. https://doi.org/10.1016/s0149-206303 00086-2

[2] Byers, T., T. Seelig, S. Sheppard, and P. Weilerstein, Entrepreneurship: Its role in engineering education. The Bridge, 2013. 43(2): p. 35-40.

[3] Holzmann, P., E. Hartlieb, and M. Roth, From Engineer to Entrepreneur-Entrepreneurship Education for Engineering Students: The Case of the Entrepreneurial Campus Villach. International Journal of Engineering Pedagogy (iJEP), 2018. 8(3): p. 28-39. https://doi.org/10.3991/ijep.v8i3.7942

[4] Lepuschitz, W., G. Koppensteiner, U. Leeb-Bracher, K. Hollnsteiner, and M. Merdan, Educational Practices for Improvement of Entrepreneurial Skills at Secondary School Level. International Journal of Engineering Pedagogy (iJEP), 2018. 8(2): p. 101-114. https://doi.org/10.3991/ijep.v8i2.8141 
[5] Zafoschnig, A. The development of the new ING-PAED IGIP curriculum into an umbrella for modularised national and regional engineering education curricula. in Interactive Collaborative Learning (ICL), 2013 International Conference on. 2013. IEEE. https://doi.org/10.1109/icl.2013.6644575

[6] Utesch, M.C., V. Seifert, L. Prifti, R. Heininger, and H. Krcmar. The Playful Approach to Teaching How to Program: Evidence by a Case Study. in International Conference on Interactive Collaborative Learning. 2017. Springer. https://doi.org/10.11 09/educon.2017.7942846

[7] Duval-Couetil, N., T. Reed-Rhoads, and S. Haghighi, The Engineering Entrepreneurship Survey: An Assessment Instrument to Examine Engineering Student Involvement in Entrepreneurship Education. Journal of Engineering Entrepreneurship, 2011. 2(2). https://doi.org/10.1109/fie.2010.5673411

[8] Wheadon, J. and N. Duval-Couetil, Elements of entrepreneurially minded learning: KEEN white paper. The Journal of Engineering Entrepreneurship, 2016(7(3)): p. 17-25.

[9] Bosman, L. and S. Fernhaber, Teaching the entrepreneurial mindset to engineers. 2018, Switzerland: Springer International Publishing. https://doi.org/10.1007/978-3-319-6141202

[10] Beiler, M.R.O., Integrating innovation and entrepreneurship principles into the civil engineering curriculum. Journal of Professional Issues in Engineering Education and Practice, 2015. 141(3). https://doi.org/10.1061/(asce)ei.1943-5541.0000233

[11] Duval-Couetil, N., E. Kisenwether, J. Tranquillo, and J. Wheadon, Exploring the Intersection of Entrepreneurship Education and ABET Accreditation Criteria. The Journal of Engineering Entrepreneurship, 2015. 6(2): p. 44-57. https://doi.org/10.7814/jeenv6n2p3

[12] Wilson, M.D., E. Holloway, and S.J. Gandhi. Entrepreneurship Education: Engineering a Pracademic Approach. in ASEE North Midwest Section Conference - Entreprenuership and Information Management. 2014. https://doi.org/10.17077/aseenmw2014.1038

[13] Bosman, L., B. Mayer, and P. McNamara. Promoting entreprenuerially minded learning through online discussions - curriculum innovation: incorporating the Kern Engineering Entrepreneurial Network (KEEN) framework into online discussions. in American Society of Engineering Education. 2017. Columbus, OH. https://doi.org/10.18260/1-2--28773

[14] Vom Brocke, J., A. Simons, B. Niehaves, K. Riemer, R. Plattfaut, and A. Cleven. Reconstructing the giant: On the importance of rigour in documenting the literature search process. in Ecis. 2009.

[15] KEEN. KEEN 3C's: Educational Outcomes. 2018; Available from: https://keenwarehouse.blob.core.windows.net/keen-downloads/KEEN_Framework_spread.pdf.

[16] Miller, D., The correlates of entrepreneurship in three types of firms. Management science, 1983. 29(7): p. 770-791. https://doi.org/10.1287/mnsc.29.7.770

[17] Covin, J.G. and D.P. Slevin, Strategic management of small firms in hostile and benign environments. Strategic management journal, 1989. 10(1): p. 75-87. https://doi.org/10.1 002/smj.4250100107

[18] Dyer, J.H., H.B. Gregersen, and C.M. Christensen, The innovator's DNA. Harvard business review, 2009. 87(12): p. 60-67.

[19] Neck, H.M., P.G. Greene, and C.G. Brush, Teaching entrepreneurship: A practice-based approach. 2014: Edward Elgar Publishing.

[20] Clifton, J. and S. Bharadwaj-Badal, Entrepreneurial strengthsfinder. 2014.

[21] Huerta, M.V., J.S. London, A. Trowbridge, M.A. Avalos, W. Huang, and A.F. McKenna. Cultivating the entrepreneurial mindset through design: Insights from thematic analysis of first-year engineering students' reflections. in ASEE Annual Conference and Exposition, Conference Proceedings. 2017. https://doi.org/10.18260/1-2--28093

[22] Liu, L., J.A. Mynderse, A.L. Gerhart, and S. Arslan. Fostering the entrepreneurial mindset in the junior and senior mechanical engineering curriculum with a multi-course problem- 
based learning experience. in Frontiers in Education Conference (FIE), 2015 IEEE. 2015. IEEE. https://doi.org/10.1109/fie.2015.7344040

[23] Creswell, J.W., Educational Research: Planning, Conducting, and Evaluating Quantitative and Qualitative Research (3rd Edition). 2008: Upper Saddle River, NJ: Pearson.

[24] Yin, R.K., Case Study Research: Design and Methods (4th Edition). 2009: Applied Social Research Methods Series Vol 5. Thousand Oaks, CA: SAGE.

[25] Yin, R.K., Case study research: Design and methods (Fifth). 2014, London, UK: SAGE Publications Ltd.

[26] Rovai, A.P., Facilitating online discussions effectively. The Internet and Higher Education, 2007. 10(1): p. 77-88. https://doi.org/10.1016/j.iheduc.2006.10.001

[27] Collison, G., B. Elbaum, S. Haavind, and R. Tinker, Effective strategies for moderators. Quarterly Review of Distance Education, 2001. 2(4): p. 397-401.

[28] Hew, K.F. and W.S. Cheung, Attracting student participation in asynchronous online discussions: A case study of peer facilitation. Computers \& Education, 2008. 51(3): p. 11111124. https://doi.org/10.1016/i.compedu.2007.11.002

[29] Larkin, T.L., A rubric to enrich student writing and understanding. International Journal of Engineering Pedagogy (iJEP), 2015. 5(2): p. 12-19. https://doi.org/10.3991/ijep.v5i2.4587

[30] Bodnar, C. and J. Kadlowec, Initial Validation of a Technical Writing Rubric for Engineering Design. International Journal of Engineering Pedagogy (iJEP), 2018. 8(1): p. 81-91. https://doi.org/10.3991/ijep.v8i1.7728

[31] Dunlap, J., Workload reduction in online courses: Getting some shuteye. International Society for Performance Improvement, 2005. May/June 2005. https://doi.org/10.100 2/pfi.4140440507

[32] Shi, M., C.J. Bonk, and R.J. Magjuka, Time Management Strategies for Online Teaching. International Journal of Instructional Technology and Distance Learning, 2006. 3(2): p. 310.

[33] Kelly, R., Group work, discussion strategies to manage online instructor workload. Retrieved from www.facultyfocus.com, 2012.

[34] Bosman, L. and T. Zagenczyk, Revitalize your teaching: Creative approaches to applying social media in the classroom, in Social media tools and platforms in learning environments. 2011, Springer. p. 3-15. https://doi.org/10.1007/978-3-642-20392-3 1

[35] Zhu, E., Interaction and cognitive engagement: An analysis of four asynchronous online discussions. Instructional Science, 2006. 34(6): p. 451-480. https://doi.org/10.1007/s11251006-0004-0

[36] Yang, Y.-T.C., A catalyst for teaching critical thinking in a large university class in Taiwan: asynchronous online discussions with the facilitation of teaching assistants. Educational Technology Research and Development, 2008. 56(3): p. 241-264. https://doi.org/10.1007/s11423-007-9054-5

[37] Ellis, R.A., P. Goodyear, R.A. Calvo, and M. Prosser, Engineering students' conceptions of and approaches to learning through discussions in face-to-face and online contexts. Learning and Instruction, 2008. 18(3): p. 267-282. https://doi.org/10.1016/j.learninstruc.2007.06.001

\section{Authors}

Lisa B. Bosman is an assistant professor at Purdue University (West Lafayette, Indiana, USA). She has a Ph.D. in Industrial Engineering and recently co-authored the book, "Teaching the Entrepreneurial Mindset to Engineers," aimed to assist faculty with integrating the entrepreneurial mindset into engineering curriculum.

Nathalie Duval-Couetil is a Professor in the Department of Technology Leadership and Innovation at Purdue University where she also serves as the Associate Director of 
the Burton D. Morgan Center for Entrepreneurship and the Director of the Certificate in Entrepreneurship and Innovation Program.

Brooke Mayer is an associate professor of environmental engineering at Marquette University in Milwaukee, Wisconsin, USA. She teaches classes and conducts research focused on the design of sustainable water and wastewater treatment systems.

Patrick McNamara is an environmental engineering educator at Marquette University in Wisconsin, USA. He is Vice Chair for the Student Services Committee of the Association for Environmental Engineering and Science Professors.

Article submitted 2018-09-04. Resubmitted 2018-10-20. Final acceptance 2018-11-02. Final version published as submitted by the authors. 